\title{
Türkiye'de fındık üretim alanlarının daraltılması politikası
}

\section{Bakiye KILIÇ TOPUZ ${ }^{\text {, Osman KILIÇ², İsmet BOZ², Gamze AYDIN ERYILMAZ }}{ }^{3}$}

\author{
${ }^{1}$ Iğdır Üniversitesi, Ziraat Fakültesi, Tarım Ekonomisi Bölümü, Iğdır \\ ${ }^{2}$ Ondokuz Mayıs Üniversitesi, Ziraat Fakültesi, Tarım Ekonomisi Bölümü, Samsun \\ ${ }^{3}$ Ondokuz Mayıs Üniversitesi, Samsun Meslek Yüksekokulu, Park ve Bahçe Bitkileri Bölümü, Samsun
}

Alınış tarihi: 16 Mayıs 2018, Kabul tarihi: 18 Ekim 2018

Sorumlu yazar: Bakiye KILIÇ TOPUZ, e-posta: bakiye.topuz@igdir.edu.tr

\section{Öz}

Türkiye'de fındık; milli gelir, istihdam ve ihracattaki öneminden dolayı stratejik bir konuma sahiptir. Türkiye'nin dünya findık üretimindeki payı 2017'de 675 bin ton ile \%67.1 olup, bunu \%13.1 ile İtalya, $\% 4.3$ ile Azerbaycan ve $\% 2.9$ ile ABD takip etmektedir. Fındık alanlarının plansız bir şekilde artması, özellikle 1980'den sonra arz fazlası sorununu ortaya çıkarmıştır. Arz fazlasının her yıl devam eden bir sorun haline gelmesi nedeniyle, 1983'de çıkarılan 2844 sayılı kanunla findık alanlarının kontrol altına alınması amaçlanmıştır. $\mathrm{Bu}$ makalede, Türkiye'de findık üretiminin önemi ve kanun sonrası illere göre fındık sökümünün yapıldı̆̆ı alanlar ile fındık yerine tercih edilen ürünler ortaya konulmuştur. Fındık alanlarının kontrol altına alınmasını amaçlayan kanun, fındık alanlarının daraltılmasında etkili olamadığı gibi, yeni fındık bahçelerinin kurulmasına da engel olamamıştır. Aksine, sökümün uygulandığı il ve ilçelerde fındık dikim alanları artmaya devam etmiştir. Fındık sökümünün gerçekleştirildiği 2002'den günümüze kadar söküm için hedeflenen üretici sayısının \%1.1'ine, hedeflenen alanın ise \%0.6'sına ulaşılabilmiștir. Söküm yapılan iller arasında \%83.4 (9.2 bin da) ile en fazla söküm yapılan alan Samsun'da gerçekleşmiştir. Bunu \%11.3 ile Sakarya ve \%3.3 ile Düzce takip etmektedir. Fındık sökümünün yapıldığı alanlarda, findık yerine en fazla tercih edilen alternatif ürünler mısır, kivi ve ceviz olmuştur.

Anahtar kelimeler: Fındık, fındık sökümü, alternatif ürünler

\section{The restriction policy of hazelnut areas in Turkey}

\section{Abstract}

Hazelnut production in Turkey is extremely important due to its contribution to national income, employment and exports. As of 2017 Turkey was responsible 675 thousand tons, for $67.1 \%$ of world hazelnut production, followed by Italy with $13.1 \%$, Azerbaijan with $4.3 \%$, and the USA with $2.9 \%$. An unplanned increase in hazelnut areas, especially after 1980, raised the issue of excess supply. As the supply surplus became an ongoing problem every year, government policy aimed to control hazelnut areas with the law numbered 2844 that was gazetted in 1983. In this paper, the importance of hazelnut production to Turkey, the post-law hazelnut areas removed from production in every province, and the alternative crops substituted for hazelnuts are examined. The law enacted to control hazelnut areas was neither effective in reducing the hazelnut areas, nor prevented the establishment of new hazelnut plantations. On the contrary, hazelnut planting areas continued to increase in provinces and districts where the removal was targeted. From 2002, when the policy of taking hazelnut areas out of production was first implemented, until the present, $1.1 \%$ of the number of producers and $0.6 \%$ of the area targeted for removal from production, has been achieved. The highest area of cases took place in Samsun Province with $83.4 \%$ (9.2 thousand decares). This was followed by Sakarya Province with $11.3 \%$ and Düzce Province with $3.3 \%$. The most preferred alternative crops to hazelnuts are corn, kiwis and walnuts.

Key words: Hazelnut, hazelnut uprooting, alternative crops 


\section{Giriş}

Dünyada 2017 yllı itibariyle, 672 bin hektar alanda 1 milyon ton findık üretimi söz konusudur. Dünyanın en büyük findık üreticisi konumunda olan Türkiye, dünya üretim alanının \%65.3'üne, üretim miktarının ise \%67.1'ine sahiptir. Dünya fındık üretiminde Türkiye'yi İtalya (\%13.1), Azerbaycan (\%4.3) ve Amerika Birleşik Devletleri (ABD) (\%2.9) izlerken, geriye kalan \%12.6'lık pay diğer ülkelere aittir. Fındık veriminin yüksek olduğu ülkeler 2017 itibariyle 246 $\mathrm{kg} / \mathrm{da}$ ile Ermenistan, $204 \mathrm{~kg} / \mathrm{da}$ ile Çin ve $203 \mathrm{~kg} / \mathrm{da}$ ile Yunanistan'dır. Dünya fındık üretiminde en fazla paya sahip olan Türkiye'nin verimi ise 2017 itibariyle dekara $154 \mathrm{~kg}$ dir (FAO, 2019).

Türkiye'de findık ekonomik ve sosyal öneminden dolayı, 1964'den itibaren alım garantisi verilerek destekleme kapsamına alınmıştır. Bu tarihten sonra uygulanan destekleme politikasının da etkisiyle, fındık dikim alanları ilk yetiştirildiği illerin dışına genişleyerek sürekli artış göstermiștir. Fındık bahçelerinin, verimin daha yüksek olduğu taban arazide yaygınlaşması nedeniyle artan üretimden dolayı, 1980'den sonra bazı yıllar önemli miktarda fındık stokları oluşmaya başlamıştır. Fındık dikim alanlarının genişlemesi kaynak israfına yol açtığı gibi, taban arazide ülke ekonomisi açısından daha önemli başka ürünlerin yetiştirilmesine de engel teşkil etmiştir. Bu durum, fındık arzını kontrol etmeye yönelik politikaların oluşturulmasını zorunlu kılmıştır (Kılıç ve ark., 2005). Bu doğrultuda 1983'de çıkarılan 2844 sayılı kanunla, fındık üretiminin en uygun alanlarda yapılması ve üretimin talepteki gelişmelere göre yönlendirilmesi amaçlanmıştır (RG, 1983). Böylece findıktan boşalacak alanlarda alternatif ürünlerin yetiștirilmesine imkân sağlanmıș olacaktır.

Türkiye'de devlet tarafından findıkta uygulanan destekleme alımı, Fındık Tarım Satıș Kooperatifleri Birliği (Fiskobirlik) aracıllğıyla 2001'e kadar devam etmiștir. Aynı yıl uygulamaya konulan ve Dünya Bankası tarafından finanse edilen "Tarım Reformu Uygulama Projesiyle (TRUP)”, Türkiye'nin tarımsal destekleme sisteminde köklü değişiklikler yapılmıştır. $\mathrm{Bu}$ projeyle, findık dâhil bitkisel ürünlerde alan bazlı doğrudan gelir desteği uygulamasına geçilmiștir. Bakanlar Kurulu tarafından 2009'da çıarılan 15201 sayılı kararla, "Yeni Fındık Stratejisi" uygulamaya konulmuştur (RG, 2009). Bu strateji kapsamında, üretime izin verilen alanlardaki fındık üreticilerine alan bazlı gelir desteği, üretime izin verilmeyen alanlardaki üreticilere ise fındık bahçelerini sökmeleri karşıllğında telafi edici ödeme desteği uygulaması başlatılmıştır.

Makalenin amacı, 2844 sayılı kanun ile daha sonraki yıllarda getirilen düzenlemeler sonrası uygulanan teşvik çerçevesinde sökülen fındık alanları ile fındıktan boşalan alanlarda tercih edilen alternatif ürünleri belirlemektir. Fındık üretim alanlarının daraltılmasının ve alternatif ürün uygulamalarının etkilerinin ortaya konulması, sürdürülebilir bir fındık üretim politikasının belirlenmesi açısından büyük önem taşımaktadır.

Çalışmada, Birleşmiş Milletler Gıda ve Tarım Örgütü (FAO), ABD Tarım Bakanlığı (USDA), Tarım ve Orman Bakanlığı (TOB), Gümrük ve Ticaret Bakanlığı (GTB) ile Türkiye İstatistik Kurumuna (TÜIK) ait veriler kullanılmıștır. Fındık sökümü yapılan alanlara ait veriler; Artvin, Düzce, Giresun, Kastamonu, Kocaeli, Ordu, Rize, Sakarya, Samsun, Sinop, Trabzon, Zonguldak, Bartın ve Gümüşhane Tarım ve Orman Bakanlığı İl ve İlçe Müdürlüklerinden alınmıştır.

\section{Türkiye'nin fındık üretim, tüketim ve dış ticaret durumu}

Türkiye'de findık üretim, tüketim ve ihracat miktarları ile yurt içi ve ihracat fiyatları yıllar itibariyle değişim göstermiş̦tir (Çizelge 1). Fındık; üretici sayısl, üretim değeri, istihdam ve özellikle ihracat geliri açısından tarım ürünleri içinde daima önemli bir ürün olma özelliğini korumuştur. Türkiye'de uygulanan destekleme politikası kapsamında devletin belirlediği fiyattan findık alım görevini, 1964'den 2002'ye kadar Fiskobirlik yapmıștır. Türkiye'de 2002'den sonra findık arzını kontrol etmeye yönelik politikalara rağmen, üretim alanları artmaya devam etmiştir. Fındık üretimi, 2002/2006 döneminde ylllk ortalama 524 bin ton iken, \%8.2'lik artışla 2012/2017 döneminde yıllık ortalama 567 bin ton olmuştur. Aynı dönemler içinde fındık ihracatında \%4.9, tüketimde ise \%47.1 oranlarında artışlar olmuştur.

Türkiye'de, yurt içi genel fiyat seviyesi ve döviz kuruna bağlı olarak, findığın yurt içi ve ihracat fiyatlarında yıllar itibariyle belirli bir artış söz konusudur. Fındığın son yıllardaki yurt içi ve ihracat fiyatlarında, önceki yıllara göre ciddi artışlar olmuştur. Türkiye, dünya findık üretiminde ilk sırada yer almasına rağmen, kişi başına fındık tüketiminde üretici olmayan birçok ülkenin altındadır. Türkiye'de yıllar itibariyle fındık tüketimi artmış, ancak nüfustaki artıştan dolayı kişi başına tüketim aynı oranda artmamıştır. Dünya fındık tüketiminin \%91 gibi büyük bir bölümü Avrupa Birliği ülkeleri 
tarafından gerçekleştirilmektedir. Dünya findık tüketiminin \%80'i çikolata ve şekerleme sanayinde ham madde olarak kullanılmaktadır (TMO, 2018).

Çizelge 1. Türkiye'de fındık üretim, tüketim, ihracat ve fiyat durumu

\begin{tabular}{|c|c|c|c|c|c|}
\hline Yll & $\begin{array}{l}\text { Üretim } \\
\text { (Bin } \\
\text { Ton) }\end{array}$ & $\begin{array}{l}\text { Tüketim } \\
\text { (Bin } \\
\text { Ton) }\end{array}$ & $\begin{array}{l}\text { İhracat } \\
\text { (İç } \\
\text { olarak) } \\
\text { (Bin } \\
\text { Ton) }\end{array}$ & $\begin{array}{c}\text { Yurt içi } \\
\text { fiyatı } \\
\text { (TL/kg) }\end{array}$ & $\begin{array}{c}\text { İhracat } \\
\text { fiyatı } \\
(\$ / \mathrm{kg})\end{array}$ \\
\hline 2002 & 600 & 80 & 157.60 & 1.67 & 2.3 \\
\hline 2003 & 480 & 70 & 136.65 & 1.89 & 4.1 \\
\hline 2004 & 350 & 60 & 134.56 & 2.50 & 8.0 \\
\hline 2005 & 530 & 60 & 131.77 & 3.97 & 8.2 \\
\hline 2006 & 661 & 80 & 158.58 & 3.76 & 5.1 \\
\hline 2007 & 530 & 80 & 140.12 & 3.79 & 7.7 \\
\hline 2008 & 801 & 100 & 134.66 & 3.78 & 4.8 \\
\hline 2009 & 500 & 90 & 128.70 & 3.87 & 6.3 \\
\hline 2010 & 600 & 100 & 149.61 & 4.23 & 6.3 \\
\hline 2011 & 430 & 100 & 146.32 & 5.38 & 7.9 \\
\hline 2012 & 660 & 130 & 161.46 & 5.47 & 5.8 \\
\hline 2013 & 549 & 120 & 162.93 & 5.06 & 7.4 \\
\hline 2014 & 450 & 80 & 147.10 & 9.38 & 12.9 \\
\hline 2015 & 646 & 90 & 143.16 & 15.03 & 9.1 \\
\hline 2016 & 420 & 90 & 133.76 & 10.54 & 8.0 \\
\hline 2017 & 675 & 110 & 160.45 & 9.94 & 6.4 \\
\hline $\begin{array}{c}2002 / \\
2006\end{array}$ & 524 & 70 & 144 & - & - \\
\hline $\begin{array}{c}2007 / \\
2011\end{array}$ & 572 & 94 & 140 & - & - \\
\hline $\begin{array}{c}2012 / \\
2017\end{array}$ & 567 & 103 & 151 & - & - \\
\hline
\end{tabular}

Kaynaklar: FAO, 2019; GTB, 2018; TÜIK, 2019

Türkiye'de findık tarımı, ilk olarak Doğu Karadeniz bölgesindeki Ordu, Giresun ve Trabzon illerinde başlamış, daha sonra Batı Karadeniz ve Marmara bölgelerindeki illere yayılmıştır. Türkiye'de fındık yetiştiriciliği, 2017 yll itibariyle 33 il ve 502 bin işletmede yapılmaktadır (TÜIKK, 2019). Fındık sektöründe doğrudan ve dolaylı olmak üzere yaklaşı 4 milyon kişi istihdam edilmektedir (USDA, 2018). Fındık üretiminin 2012/2017 döneminde dörtte birini (\%26.9) Ordu karşılamakta, bunu Sakarya (\%15.5), Samsun (\%14.3), Giresun (\%13.2) ve diğer iller takip etmektedir (Çizelge 2).

\section{Türkiye'nin findık üretim politikası}

Türkiye'nin dünya findık üretim ve ihracatında önemli bir ülke olması, findıkla ilgili stratejilerin ve ileriye dönük politikaların olușturulmasını zorunlu kılmaktadır. Türkiye'de fındıkta uygulanan fiyat destekleme politikasının etkisiyle, özellikle 1980'den sonra bazı yıllar oluşan arz fazlası nedeniyle arz-talep dengesi bozulmuştur. Bu durum, findık dikim alanlarının sınırlandırılmasını gündeme getirmiş ve bunun sonucu olarak 1983'de 2844 sayll "Findlk Üretiminin Planlanması ve Dikim Alanlarının Belirlenmesi" hakkında kanun çıkarılmıştır. Bu kanunla, izin alınmadan yeni fındık bahçelerinin kurulması ve belirlenen alanlar dışında mevcut fındık bahçelerinin yenilenmesinin yasaklanması, ayrıca arz fazlası olan üretim alanlarının arz açığı olan ürünlere kaydırılması amaçlanmıştır (RG, 1983). Bu kapsamda doğrudan gelir ödemesi çerçevesinde, Bakanlar Kurulu tarafindan 24.04.2001'de 2218 sayılı "Findık Alanlarının Tespitine ve Sökülen Fındık Bahçeleriyle Birlikte Yerine Alternatif Ürün Yetiștireceklerin Desteklenmesine Dair Karar" yürürlüğe girmiştir (RG, 2001). Buna göre, izin verilen alanlar dışında kalan fındık bahçelerinin sökülmesine ve söküm masraflarının devlet tarafından karşılanmasına karar verilmiştir. Karar kapsamında yaklaşık 150 milyon doların, fındık dışındaki alternatif ürünlerin yetiştirilmesi için kullanılması kararlaştırılmıştır (TZOB, 2010).

Fındığın desteklenmesi, Bakanlar Kurulu'nun 15.07.2009 tarih ve 2009/15201 sayılı kararıyla, "Yeni Findık Stratejisi" adı altında yeniden düzenlenmiştir. Yeni düzenlemeyle, ruhsatlı alanlarda üretim yapan fındık üreticilerine "Alan Bazlı Gelir Desteği", ruhsatsız alanlarda findık yetiştiriciliği yapanlara ise alternatif ürünlere geçmeleri halinde "Telafi Edici Ödeme" yapılması kararlaştırılmıştır (RG, 2009). Kanun çerçevesinde birçok defa değişikliğe uğrayan ruhsatlı üretim alanları, 27.10.2009'da çıkarılan 15531 sayılı Bakanlar Kurulu Kararı'yla 14 ille sınırlandırılmıştır. Kararla, belirlenen ve ruhsat verilen alanlarda findik yetiştiriciliği yapan ve fındık üretici belgesine sahip kamu kurum ve kuruluşları hariç, gerçek ve tüzel kişilere yılda bir defaya mahsus olmak üzere 2009, 2010 ve 2011'de her yll için dekara 150 TL alan bazlı gelir desteği ödemesi yapılması kararlaştırılmıștır. Ayrıca findık alanlarının tespitine dair kararın, 1'inci maddesinde belirtilen il ve ilçelerdeki 1'inci, 2'inci ve $\% 6$ 'dan daha az eğimli 3'üncü sınıf tarım arazilerindeki bahçeler ile rakımı 750 metrenin üzerindeki ruhsatsız fındık bahçelerini sökerek, alternatif ürünlere geçen kamu kurum ve kuruluşları hariç, gerçek ve tüzel kişilere 2009-2012 yıllarında telafi edici ödeme yapılması kararlaştırılmıștır. Bu alanlarda, yeni fındık bahçelerinin tesis edilmesine ve 
yenilenmesine izin verilmemektedir. Bu kapsamda ruhsatsız findık bahçelerini sökerek, alternatif ürünlere geçen üreticilerden 2009/2010 üretim döneminde başvuranlara, ilk yıl için 300 TL, ikinci ve üçüncü yıllar için 150 TL olmak üzere 3 yılda dekara toplam 600 TL, 2010/2011 döneminde başvuranlara ilk yıl için 300 TL, ikinci yıl için 150 TL olmak üzere 2 yılda dekara toplam 450 TL, 2011/2012 döneminde başvuranlara ise dekara 300 TL telafi edici ödeme yapılması kararlaştırılmıştır (RG, 2009).

Çizelge 2. Türkiye'de illere göre fındık üretim miktarları (ton)

\begin{tabular}{|c|c|c|c|c|c|c|c|c|}
\hline \multirow[b]{2}{*}{ İller } & \multirow[b]{2}{*}{2012} & \multirow[b]{2}{*}{2013} & \multirow[b]{2}{*}{2014} & \multirow[b]{2}{*}{2015} & \multirow[b]{2}{*}{2016} & \multirow[b]{2}{*}{2017} & \multicolumn{2}{|c|}{$2012 / 2017$} \\
\hline & & & & & & & $\begin{array}{c}\text { Yillık } \\
\text { ortalama }\end{array}$ & $(\%)$ \\
\hline Ordu & 145353 & 178357 & 84874 & 200938 & 93030 & 213572 & 152687 & 26.9 \\
\hline Sakarya & 118057 & 64540 & 94895 & 82708 & 77279 & 88840 & 87720 & 15.5 \\
\hline Samsun & 88392 & 69392 & 73544 & 90857 & 67855 & 96240 & 81047 & 14.3 \\
\hline Giresun & 101532 & 81342 & 31567 & 105023 & 37591 & 93339 & 75066 & 13.2 \\
\hline Düzce & 81278 & 48295 & 69503 & 69344 & 54493 & 74350 & 66211 & 11.7 \\
\hline Trabzon & 58767 & 44537 & 31065 & 39126 & 28978 & 41594 & 40678 & 7.2 \\
\hline Zonguldak & 25890 & 19105 & 30148 & 22572 & 28428 & 30932 & 26179 & 4.6 \\
\hline Artvin & 9414 & 14420 & 9346 & 6314 & 5022 & 4149 & 8111 & 1.4 \\
\hline Kocaeli & 10524 & 8531 & 7323 & 7530 & 7033 & 11898 & 8807 & 1.6 \\
\hline Bartın & 7016 & 5684 & 6688 & 6765 & 7153 & 5972 & 6546 & 1.2 \\
\hline Kastamonu & 4993 & 5102 & 4231 & 5213 & 5769 & 6210 & 5253 & 0.9 \\
\hline Rize & 1633 & 1377 & 1122 & 1303 & 881 & 1331 & 1275 & 0.2 \\
\hline Sinop & 1024 & 1112 & 1078 & 1175 & 1080 & 1118 & 1098 & 0.2 \\
\hline Gümüşhane & 903 & 876 & 878 & 723 & 483 & 500 & 727 & 0.1 \\
\hline Bolu & 299 & 290 & 364 & 366 & 228 & 225 & 295 & 0.1 \\
\hline Diğerleri (18 il) & 4925 & 6040 & 3374 & 6043 & 4697 & 4730 & 4968 & 0.9 \\
\hline Toplam & 660000 & 549000 & 450000 & 646000 & 420000 & 675000 & 566667 & 100.0 \\
\hline
\end{tabular}

Kaynak: TÜIK, 2019

Bakanlar Kurulu tarafından 2009'da çıkarılan 15201 sayılı karar, 10.04.2010 tarihinde yeniden düzenlenmiștir. Bu düzenlemeyle, fındık üretimine izin verilen alanlarda yer alan hazine ve orman arazisinde, kiralama ve tahsis yoluyla findık üretimi yapan ve çiftçi kayıt sistemine kayıtlı üreticilerin destekleme ödemelerinden yararlanacakları ifade edilmektedir. Ayrıca belirtilen alanların dıșında kalan yerlerde findık üretimi yapan üreticilerin, kararda belirtilen destekleme ödemelerinden yararlanamayacakları vurgulanmıștır. İlgili kararla, son olarak 24.02.2011 tarih ve 1424 sayll BKK'yla fındık üretimine izin verilen alanlar, Çizelge 3'de belirtildiği gibi yeniden düzenlenmiştir.

Türkiye'de yeni fındık stratejisinin (Alan Bazlı Gelir Desteği ve Alternatif Ürüne Geçen Üreticilere Telafi Edici Ödeme Yapılmasına Dair Karar), 28.01.2013 tarih ve 2013/4245 sayılı BKK'yla 2012-2014 yıllarında da devam etmesi kararlaştırılmıștır. Karara göre, 22.11.2001 tarih ve 2001/3267 sayll BKK'yla yürürlüğe konulan "Fındık Alanlarının Tespitine Dair
Karar'la belirlenen ve ruhsat verilen alanlarda findık yetiştiriciliği yapan ve fındık üretici belgesine sahip kamu kurum ve kuruluşları hariç, gerçek ve tüzel kişilere 2012 için dekara 150 TL, 2013 için dekara 160 TL ve 2014 için dekara 170 TL alan bazlı gelir desteği ödemesi yapılması kararlaştırılmıştır.

Fındık alanlarının tespitine dair kararın 1'inci maddesinde belirtilen il ve ilçelerdeki (14 il, 105 ilçe) 1'inci, 2'inci ve \%6'dan daha az eğimli 3'üncü sınıf tarım arazilerinde, ruhsatsız fındık bahçelerini sökerek alternatif ürünlere yer veren kamu kurum ve kuruluşları hariç, gerçek ve tüzel kişilere 2012-2014 yıllarında telafi edici ödeme desteği yapılması kararlaştırılmıştır. Telafi edici ödeme desteği, 2012 için başvuranlara ilk yıl için dekara 300 TL, ikinci ve üçüncü yıllarda ise her yıl için dekara 150 TL olmak üzere 3 yılda dekara toplam 600 TL, 2013 için başvuranlara, ilk yıl için dekara 300 TL, ikinci yıl için dekara 150 TL olmak üzere 2 yılda dekara toplam 450 TL, 2014 için başvuranlara ise dekara 300 TL olarak belirlenmiştir (RG, 2013). 
Çizelge 3. Fındık üretimine izin verilen il ve ilçeler

\begin{tabular}{ll}
\hline İller & İlçeler \\
\hline Artvin & Borçka, Arhavi, Hopa, Murgul \\
\hline \multirow{2}{*}{ Düzce } & $\begin{array}{l}\text { Merkez, Akçakoca, Cumayeri, Gölyaka, Çilimli, } \\
\text { Gümüşova, Yığılca, Kaynaşlı }\end{array}$ \\
\hline \multirow{2}{*}{ Giresun } & $\begin{array}{l}\text { Merkez, Bulancak, Keşap, Tirebolu, Görele, } \\
\text { Eynesil, Espiye, Dereli, Çanakçı, Güce, } \\
\text { Doğankent, Yağlıdere, Piraziz }\end{array}$ \\
\hline Kastamonu & $\begin{array}{l}\text { Abana, Bozkurt, Cide, Çatalzeytin, İnebolu, } \\
\text { Doğanyurt }\end{array}$ \\
\hline Kocaeli & Kandıra \\
\hline Ordu & Bütün ilçeler \\
\hline Rize & Ardeşen, Fındıklı, Pazar \\
\hline Sakarya & $\begin{array}{l}\text { Kocaali, Karasu, Akyazı, Hendek, Ferizli, } \\
\text { Karapürçek, Kaynarca }\end{array}$ \\
\hline \multirow{3}{*}{ Samsun } & $\begin{array}{l}\text { Çarşamba, Terme, Ayvacık, Salıpazarı, 19 Mayıs, } \\
\text { Tekkeköy, Alaçam, Yakakent, Illkadım, Bafra, }\end{array}$ \\
\hline Sinop & Asarcık, Canik, Atakum \\
\hline Trabzon & Bütün ilçeler \\
\hline Zonguldak & Alaplı, Ereğli \\
\hline Bartın & Merkez, Amasra, Kurucaşile, Ulus \\
\hline Gümüşhane & Kürtün \\
\hline
\end{tabular}

Kaynak: RG, 2011

\section{Sökülen fındık alanları ve alternatif ürünler}

Türkiye'de alternatif ürün projesiyle, 81 bin üreticiye ait 176 bin hektar fındık bahçesinin sökülmesi hedeflenmiştir (TOB, 2018). Sökülen alanlarda fındık yerine önerilen alternatif ürünler; ayçiçeği, mısır, silajlık mısır, açıkta sebze, örtü altı sebze, soya fasulyesi, kolza, fiğ, üzümsü meyve, çilek, kivi, Trabzon hurması, yonca, kuşburnu, süs çalıları, sarımsak, aromatik ve tıbbi bitkilerdir (Akdamar, 2001).

Fındık üretim alanlarının sınırlandırılmasıyla ilgili yönetmelik 1989'da yürürlüğe girmesine rağmen, fındık sökümüne 2002'den sonra başlanmıştır. Alternatif ürün projesi kapsamında, 2002-2014 arasında 929 işletmede findık sökümü yapılmıştır. Türkiye'de işletme sayısı olarak, fındık sökümü yapılan iller arasında ilk sırayı \%73.5 ile Samsun almaktadır. Bunu Sakarya (\%15.7), Düzce (\%7.3) ve Ordu (\%1.8) takip etmektedir. Buna göre, Türkiye'de ilgili kanun gereğince fındık sökümü gerçekleștiren işletmelerin tamamına yakınını (\%98.3) Samsun, Sakarya, Düzce ve Ordu'daki işletmeler oluşturmaktadır. Türkiye genelinde sökümü gerçekleştirilen 11033.9 da findık üretim alanının \%83.4'ü Samsun, \%11.3'ü Sakarya, \%3.3'ü Düzce ve \%1.2'si Ordu'ya aittir. Giresun, Kastamonu, Kocaeli, Zonguldak ve Rize'de ise findık sökümü azdır. Sökümün yapılacağı iller arasında olmalarına rağmen, Artvin, Sinop, Trabzon, Bartın ve
Gümüşhane'de findık sökümü gerçekleşmemiştir (Çizelge 4).

Alternatif ürün projesi kapsamında, findık sökümünde hedeflenen üretici sayısının \%1.1'ine, hedeflenen alanın ise ancak \%0.6'sına ulaşılabilmiştir. Projedeki hedefin sağlanamamasında; piyasaya müdahalenin sürmesi nedeniyle fındıkla ilgili yüksek fiyat beklentisinin devam etmesi, alternatif ürün desteğinin üreticileri tatmin etmemesi, fındık üreticilerinin bir kısmının il ya da ilçe merkezlerinde ikamet etmeleri, alternatif ürünlerin fındığa göre daha çok zaman ve işgücü gerektirmesinin etkili olduğu belirtilmektedir. Diğer başarısızlık nedenleri olarak; fındık üretim alanlarının bir kısmının kadastro geçmemiş ya da orman vasfını yitirmiş alanlar içinde olması nedeniyle üreticilerin arazisini kaybetme endişesi taşıması, alternatif ürünlerle ilgili depolama ve pazarlama endişesi ve alternatif ürünlerin fındık kadar gelir getirmeyeceği görüşünün hâkim olması sayılabilir (TZOB, 2010).

Türkiye'de sökümü yapılan findık alanlarında en fazla tercih edilen alternatif ürün dane mısırdır. Diğer alternatif ürünler; kivi, ceviz, yem bitkileri (fiğ, silajlık mısır, yonca, yulaf karışımı), soya, buğday, kanola, ayçiçeği, elma, armut, domates, karışık sebze ve çeltiktir. En fazla söküm yapılan Samsun, Sakarya ve Düzce'de alternatif ürün olarak silajlık mısır ve diğer yem bitkileri öne çıkmaktadır (Çizelge 4).

\section{Sonuç ve Öneriler}

Türkiye'de findıkta uygulanan destekleme politikasının etkisiyle, artan üretime paralel olarak ihracat ve iç tüketim aynı oranda artırılamamıştır. Bunun sonucu olarak, özellikle 1980'den sonra findık arzı talebin üzerine çıkmış ve arz-talep dengesi bozulmuştur. $\mathrm{Bu}$ durum ihracat ve iç tüketimi artırmaya yönelik geliştirilen politikalarla birlikte, mevcut fındık alanlarının daraltılmasının da gerekli olduğunu gündeme getirmiştir. Bu kapsamda, arz fazlası fındık alanlarının sökülerek arz açığı olan ürünlere kaydırılması ve alternatif ürünlere yer veren üreticilere telafi edici ödeme yapılmasına yönelik teşvik uygulamasına başlanmıştır. Ancak telafi edici ödemeye rağmen, fındık alanlarında azalma olmadığı gibi, ihracat ve iç tüketim miktarlarında da istenen düzeyde artışlar olmamıştır. Bu dönemde, söküm için hedeflenen işletme sayısı ve alanın çok azına ulaşılmıştır. Dolayısıyla sökümle ilgili telafi edici ödeme politikasının, fındık alanlarının daraltılmasıyla ilgili hedefin sağlanmasında etkili olduğu söylenemez 
Çizelge 4. Türkiye'de illere göre sökümü yapılan findık alanları ve alternatif ürünler (2002-2014)

\begin{tabular}{|c|c|c|c|c|}
\hline İller & İlçeler & İşletme sayısı & Sökülen alan (dekar) & Alternatif ürünler \\
\hline \multirow{6}{*}{ Düzce } & Merkez & 34 & 167.8 & \multirow{7}{*}{$\begin{array}{l}\text { Silajlık mısır, yem bitkileri, yonca, fiğ, } \\
\text { armut }\end{array}$} \\
\hline & Çilimli & 16 & 104.1 & \\
\hline & Gölkaya & 4 & 17.3 & \\
\hline & Gümüşova & 2 & 10.0 & \\
\hline & Kaynaşlı & 6 & 14.5 & \\
\hline & Cumayeri & 6 & 46.5 & \\
\hline Toplam & & 68 & 360.2 & \\
\hline Giresun & Bulancak & 1 & 3.0 & Domates \\
\hline Kastamonu & Cide & 1 & 1.0 & Elma \\
\hline Kocaeli & Kandıra & 8 & 67.9 & Misir \\
\hline \multirow{5}{*}{ Ordu } & Gülyalı & 2 & 7.0 & \multirow{6}{*}{ Kivi, ceviz, buğday, mısır, karışık sebze } \\
\hline & Fatsa & 7 & 46.8 & \\
\hline & Ünye & 6 & 46.4 & \\
\hline & Merkez & 1 & 10.6 & \\
\hline & Korgan & 1 & 22.1 & \\
\hline Toplam & & 17 & 132.9 & \\
\hline Rize & Findıklı & 1 & 1.6 & Kivi \\
\hline \multirow{11}{*}{ Sakarya } & Akyazı & 25 & 262.4 & \multirow{12}{*}{ Mısır, ceviz } \\
\hline & Hendek & 74 & 604.1 & \\
\hline & Ferizli & 8 & 78.9 & \\
\hline & Söğütlü & 5 & 76.3 & \\
\hline & Geyve & 3 & 18.5 & \\
\hline & Merkez & 3 & 16.6 & \\
\hline & Sapanca & 3 & 22.0 & \\
\hline & Karapürçek & 7 & 86.4 & \\
\hline & Karasu & 8 & 48.8 & \\
\hline & Kaynarca & 7 & 27.8 & \\
\hline & Kocaali & 3 & 8.4 & \\
\hline Toplam & & 146 & 1250.2 & \\
\hline \multirow{7}{*}{ Samsun } & Merkez & 1 & 12.1 & \multirow{8}{*}{$\begin{array}{l}\text { Soya, çeltik, yem bitkisi (fiğ, dane mısır, } \\
\text { silajlık mısır, yulaf karışımı), buğday, } \\
\text { kanola, ayçiçeği }\end{array}$} \\
\hline & Çarşamba & 293 & 3627.1 & \\
\hline & Salıpazarı & 112 & 813.1 & \\
\hline & Tekkeköy & 9 & 87.3 & \\
\hline & Terme & 266 & 4644.4 & \\
\hline & Ayvacık & 1 & 11.0 & \\
\hline & 19 Mayıs & 1 & 3.0 & \\
\hline Toplam & & 683 & 9198.0 & \\
\hline \multirow{2}{*}{ Zonguldak } & Ereğli & 1 & 7.0 & \multirow{3}{*}{ Kivi, ceviz } \\
\hline & Alaplı & 3 & 12.1 & \\
\hline Toplam & & 4 & 19.1 & \\
\hline Artvin & Söküm yok & & & \\
\hline Sinop & Söküm yok & & & \\
\hline Trabzon & Söküm yok & & & \\
\hline Bartın & Söküm yok & & & \\
\hline Gümüşhane & Söküm yok & & & \\
\hline Genel Toplam & & 929 & 11033.9 & \\
\hline
\end{tabular}

Kaynak: TOB, 2017 
Fındık alanlarının daraltılması amacıyla getirilen telafi edici ödeme uygulamasına 2014'den sonra son verilmiştir. Fındık alanlarının daraltılmasıyla ilgili belirlenen hedefe ulaşmak için, telafi edici ödeme miktarı fındık ile alternatif ürünler arasındaki kâr farkını göz önüne alacak şekilde yeniden düzenlenmelidir. Bu amaçla öncelikle yapılacak alan çalışmalarıyla, fındık ve alternatif ürünlerde üretim maliyeti ile birim alana düşen kârın belirlenmesi gerekir. Alternatif ürünlerin en az fındık kadar kârlı olmasının yanı sıra, alternatif ürünlere belli bir süre satın alma garantisinin verilmesi sağlanabilir. Ayrıca alternatif ürünlerin ihracat imkânı bulunan ürünlerden seçilmesine öncelik verilmesi önemlidir. Fındık üreticilerinin alternatif ürünlerin yetiştiriciliği konusundaki bilgi eksikliklerinin giderilmesi için, ilgili kurumlar tarafından eğitim faaliyetleri düzenlenmelidir. Türkiye'de findık üretici örgütlerini de içine alan ve büyük ölçüde ihracata dönük, sürdürülebilir bir findık üretim planlamasının önemini göz ardı etmemek gerekir.

Yeni findık stratejisi sonrası devletin findık piyasasından çekilmesi, fındık üreticilerinin piyasadaki tüccarlarla karşı karşıya kalmasına yol açmıştır. Hâlbuki etkin bir tarımsal örgütlenmenin varlığı, özellikle küçük fındık üreticileri için büyük önem taşımaktadır. Üreticilerin serbest piyasada güçlü olabilmeleri, üretici örgütlerinin pazarlamada daha etkin rol almalarına bağlıdır. Bu bağlamda tarımsal desteklerin üretici örgütleri aracılı̆̆ıyla verilmesi bir araç olarak düşünülebilir. Arz fazlası olan yıllarda ise piyasa dengesinin sağlanmasında, devletin iç ve dış piyasada aktif rol almasının gereği kaçınılmazdır.

Türkiye'nin dünya findık üretimi ve ihracatındaki üstün konumu devam etmesine rağmen, rakip ülkeler üretim ve ihracatlarını hızla artırmaktadırlar. Dolayısıyla diğer ülkelerin üretimlerini artırma stratejilerine karşı tedbirler alınmazsa, Türkiye'nin fındık üretimindeki üstünlüğünden dolayı ihracatta sağladığı avantajlı konumunun gelecekte de devam etmesi kolay olmayacaktır. Bu bakımdan Türkiye'nin, fındıkta verim ve kalite artışına öncelik vermesi ve buna yönelik teşvik politikalarını geliştirmesi öncelikli hedefler arasında yer almalıdır.

\section{Kaynaklar}

Akdamar, M., 2001. Alternatif Ürün (Ürün Geçiş) Programı. T.C. Tarım ve Köy İşleri Bakanlığı, Tarımsal Üretim ve Geliștirme Genel Müdürlüğü, Eğitim Semineri Notları, Ankara.
FAO, 2019. Food and Agriculture Organization. http://www.fao.org/faostat/en/\#data, (Erişim tarihi: 26.06.2019).

GTB, 2018. Gümrük ve Ticaret Bakanlığı, Kooperatifçilik Genel Müdürlüğü, 2017 Yılı Fındık Raporu. Nisan 2018, Ankara, file:///C:/Users/Exper3/Desktop /2017\%20F\%C4\%B1nd\%C4\%B1k\%20Raporu.pdf, (Erişim tarihi: 15.07.2018).

Kılıç, O., Cinemre, H.A., Ceyhan, V., Bozoğlu, M., 2005. Samsun ili Çarşamba ve Terme ilçelerinin ova kesiminde fındığa alternatif üretim planlaması. T.C. Başbakanlık Devlet Planlama Teşkilatı, Teknolojik Araştırma Projesi, Proje no: TAP-012.

Resmi Gazete, 1983. Fındık Üretiminin Planlanması ve Dikim Alanlarının Belirlenmesi Hakkında Kanun. Kanun No: 2844, Kabul Tarihi: 16.06.1983.

Resmi Gazete, 2001. Fındık Alanlarının Tespitine Dair Kararın Yürürlüğe Konulması Hakkında Karar. Karar Sayısı: 3267, Karar Tarihi: 27.11.2001.

Resmi Gazete, 2009. Fındık Üreticilerine Alan Bazlı Gelir Desteği ve Alternatif Ürüne Geçen Üreticilere Telafi Edici Ödeme Yapılmasına Dair Karar. Karar Sayısı: 27289, Karar Tarihi: 15.07.2009.

Resmi Gazete, 2011. Fındık Alanlarının Tespitine Dair Kararda Değişiklik Yapılması Hakkında Karar. Karar Sayısı: 27389, Karar Tarihi: 24.02.2011.

Resmi Gazete, 2013. Fındık Üreticilerine Alan Bazlı Gelir Desteği ve Alternatif Ürüne Geçen Üreticilere Telafi Edici Ödeme Yapılmasına Dair Karar. Karar Sayısı: 4245, Karar Tarihi: 30.01.2013.

TMO, 2018. Toprak Mahsulleri Ofisi. 2013/08 Sayılı Fındık Bülteni. http://www.tmo.gov.tr/Upload/Document /bultenler/2013/0508findikbultn.pdf, (Erişim tarihi: 15.05.2018).

TOB, 2017. Tarım ve Orman Bakanlığ Artvin, Düzce, Giresun, Kastamonu, Kocaeli, Ordu, Rize, Sakarya, Samsun, Sinop, Trabzon, Zonguldak, Bartın ve Gümüşhane İl ve İlçe Müdürlükleri Kayıtları.

TOB, 2018. Tarım ve Orman Bakanlığı, Strateji Geliştirme Başkanlığl, http://www2.tbmm.gov.tr/d24/7/761680c.pdf (Erişim tarihi: 13.05.2018).

TÜİK, 2019. Türkiye İstatistik Kurumu, https://biruni.tuik.gov.tr/medas/?kn=92\&locale=t r, (Erişim tarihi: 26.06.2019). 
TZOB, 2010. Türkiye Ziraat Odaları Birliği, Zirai ve İktisadi Rapor 2007-2010. Ankara, https://www.tzob.org.tr /zirai-iktisadi-raporlar, (Erişim tarihi: 16.05.2018).
USDA, 2018. United States Department of Agriculture, Turkey Tree Nuts Annual Report 2014. Gain Report Number: TR4037. https://gain.fas.usda.gov /Recent\%20GAIN\%20Publications/Tree\%20Nuts \%20 Annual_Ankara_Turkey_10-16- 2014.pdf, (Erişim tarihi: 14.05.2018). 